\title{
Article \\ Systemic Antibiotic and Nonsteroidal Anti-Inflammatory Drug Treatment Decreases the Level of Endogenous Angiogenic Vascular Endothelial Growth Factor in Inflamed Human Periapical Tissues
}

\author{
Aleksandra Palatyńska-Ulatowska ${ }^{1, * D}$, Marta Michalska ${ }^{2}$, Anna Drelich $^{2}$, Aleksandra Sałagacka-Kubiak ${ }^{3}$ (D), \\ Ewa Balcerczak ${ }^{3}$ (D) Bogusława Manowska ${ }^{4}$ and José Antonio Poli de Figueiredo 5
}

check for updates

Citation: Palatyńska-Ulatowska, A.; Michalska, M.; Drelich, A.;

Sałagacka-Kubiak, A.; Balcerczak, E.; Manowska, B.; Poli de Figueiredo, J.A Systemic Antibiotic and Nonsteroidal Anti-Inflammatory Drug Treatment Decreases the Level of Endogenous Angiogenic Vascular Endothelial Growth Factor in Inflamed Human Periapical Tissues. Appl. Sci. 2021, 11, 4976. https://doi.org/10.3390/ app11114976

Academic Editor: Luca Testarelli

Received: 9 May 2021

Accepted: 25 May 2021

Published: 28 May 2021

Publisher's Note: MDPI stays neutral with regard to jurisdictional claims in published maps and institutional affiliations.

Copyright: (C) 2021 by the authors Licensee MDPI, Basel, Switzerland. This article is an open access article distributed under the terms and conditions of the Creative Commons Attribution (CC BY) license (https:/ / creativecommons.org/licenses/by/ $4.0 /$ )
1 Department of Endodontics, Chair of Conservative Dentistry and Endodontics, Medical University of Lodz 251 Pomorska Str., 92-217 Lodz, Poland

2 Department of Pharmaceutical Biochemistry, Medical University of Lodz, 1 Muszyńskiego Str., 90-151 Lodz, Poland; martabioch444@gmail.com (M.M.); ania.fras00@gmail.com (A.D.)

3 Laboratory of Molecular Diagnostics and Pharmacogenomics, Department of Pharmaceutical Biochemistry and Molecular Diagnostics, Medical University of Lodz, 1 Muszyńskiego Str., 90-151 Lodz, Poland; aleksandra.salagacka@umed.lodz.pl (A.S.-K.); ewa.balcerczak@umed.lodz.pl (E.B.)

4 Department of Maxillofacial Surgery, Medical University of Lodz, 113th S. Żeromskiego, 90-549 Lodz, Poland boguslawa.manowska@umed.lodz.pl

5 Department of Morphological Sciences, Federal University of Rio Grande do Sul-UFRGS, Rua Sarmento Leite 500 sala 134, Porto Alegre CEP 90050-170, Brazil; poli.figueiredo@outlook.com

* Correspondence: aleksandra.palatynska-ulatowska@umed.lodz.pl

Abstract: Vascular endothelial growth factor (VEGF)-induced angiogenesis contributes to inflammatory bone resorption in humans. Widely documented antagonists to resorption include antibiotics and non-steroidal anti-inflammatory drugs (NSAIDs). The purpose of this study was to investigate the effect of these drugs on proangiogenic VEGF levels in periradicular lesions. Periapical tissue biopsies were obtained from 42 patients with chronic periapical periodontitis. VEGF levels were measured using a commercial ELISA kit in patients divided into groups according to treatment: no drugs (control group, $n=25)$, NSAIDs $(n=7)$, antibiotics $(n=5)$, and NSAIDs and antibiotics $(n=5)$. Reverse transcriptase (RT) reaction was performed in all the samples under analysis. Presence of $V E G F A$ and $V E G F B$ gene expression was assessed using reverse-transcription-polymerase chain reaction (RT-PCR). ELISA analysis indicated that average VEGF levels in tissue samples of patients treated with NSAIDs $(6.097 \pm 1.930 \mathrm{ng} / \mathrm{mL})$, antibiotics (5.661 $\pm 2.395 \mathrm{ng} / \mathrm{mL})$, and NSAIDs and antibiotics $(7.142 \pm 2.601 \mathrm{ng} / \mathrm{mL})$ were significantly lower than in samples of control patients $(10.432 \pm 4.257 \mathrm{ng} / \mathrm{mL}$, ANOVA $p=0.008)$. The RT-PCR did not reveal VEGFA gene expression in any of the 42 samples. VEGFB gene expression was found in 26 of 42 samples $(69.1 \%)$. The use of NSAIDs or antibiotics in patients with exacerbated chronic periodontitis decreases VEGF levels in periapical tissues. Pharmacotherapy may minimize the effects of VEGF on apical periodontitis progression in that way.

Keywords: endodontic treatment; periapical periodontitis; antibiotics; nonsteroidal anti-inflammatory drugs; polymerase chain reaction (PCR); vascular endothelial growth factor

\section{Introduction}

In chronic periapical periodontitis, there is a dynamic balance between the bacteria in the canal system and the host response in surrounding tissues. When this balance is disturbed, exacerbation occurs spontaneously with severe symptoms due to the local production of pro-inflammatory and immune factors. Inflamed tissues increase the expression of various cytokines and growth factors that promote angiogenesis. One of the proangiogenic proteins responsible for greater proliferation of endothelial cells, new vessel 
formation and vascular permeability is the vascular endothelial growth factor (VEGF). VEGF-induced angiogenesis may contribute to the progression of inflammation, because the new blood vessels transport oxygen, nutrients and pro-inflammatory cells to the inflamed tissues [1]. Furthermore, persistent inflammation contributes to bone resorption, followed by bone replacement with granulomatous tissue and formation of periapical granulomas, leading to periodontitis progression. Studies have shown that VEGF expression is an important factor in granulation tissue development and cyst enlargement [2]. VEGF expression is significantly different in all cell components of keratocysts and follicular cysts. This expression in epithelial cells and in capsular fibroblasts is correlated with vessel formation, which suggests that these cells form a network that is regulated by angiogenesispromoting signals. Angiogenesis seems to be an active mechanism in the invasive growth of odontogenic keratocysts [3]. VEGF receptors in osteoclasts suggest that this growth factor may affect bone resorption [4]. Veeriah and colleagues found that the mechanical unloading of bone by treatment with Botox, known to reduce bone mass, prompted the overexpression of VEGF in osteoblasts [5]. Likewise, bone repair and healing depend on VEGF-stimulated angiogenesis. Histological and immuno-histochemical analyses confirmed that the application of topical ozone gas increases VEGF expression and, therefore, may be effective in the early stages of wound healing [6]. These findings suggest that VEGF is a significant signaling molecule in the communication between endothelial cells and osteoblasts [7]. Nevertheless, data about its role in periodontal lesions are still limited.

VEGF-A, one of the VEGF family members (VEGF-A, VEGF-B, VEGF-C, VEGF-D) is a prototype angiogenic factor with a potent and universal angiogenic effect under most physiological and pathological conditions [8,9]. VEGF-C and VEGF-D are primarily involved in lymphangiogenesis $[10,11]$, whereas VEGF-B is a survival factor for different types of cells, and not an angiogenic agent per se, as it inhibits apoptosis by suppressing the expression of genes associated with apoptosis and cell death [12]. Therefore, it is critical for blood vessel survival, is highly expressed in most tissues and organs and may be a potential treatment for some vascular and neurodegenerative diseases [13]. In vitro treatment with VEGF-B protein seems to rescue blood vessel cells from apoptosis [14].

Recent studies reported on the effect of antibiotics on the reduction of VEGF levels in many types of human tissues, such as those from the colon [15], skin [16], pancreas [17] and female genitals [18]. Studies with colecoxib [19], aspirin [20] and meloxicam [21] confirmed the inhibitory effect of non-steroidal anti-inflammatory drugs (NSAIDs) on VEGF levels. In acute and exacerbated chronic periapical periodontitis, antibiotics and NSAIDs are the drugs most often prescribed by dentists for pain management [22]. Oral infections accompanied by elevated body temperature and signs of systemic spread, such as lymphadenopathy and facial cellulitis, are clinical situations that require antibiotic management, which should be promptly implemented because of possible spread via lymph and blood circulation. Antibiotics are also indicated for a limited number of localized oral lesions, such as periodontal abscesses, acute necrotizing ulcerative gingivitis and pericoronitis [23].

Systemic management is indicated as an adjuvant therapy to control pain, inflammation and infection, providing greater comfort for the patient. The role of anti-inflammatory drugs in the pathogenesis of periodontitis is associated with the inhibition of matrix metalloproteinases, the reduction of prostaglandin levels and the inhibition of cyclooxygenases (COX-1, COX-2) involved in inflammation and pain signaling pathways [24].

Despite these findings, the activity of antibiotics and anti-inflammatory drugs and their possible effects on the levels of proangiogenic factors remain unclear. Therefore, this study evaluated whether antibiotics and NSAIDs often used in the exacerbated phase of chronic periradicular periodontitis affect the level of VEGF in periapical lesions. Moreover, it assessed the presence of VEGF gene expression in inflamed human periapical tissues that received treatment with these commonly used drugs, or that did not receive any treatment. 


\section{Materials and Methods}

Biopsies of periapical inflamed tissues were obtained from 42 patients aged 20-71 who were diagnosed with chronic periapical periodontitis at the time of tooth extraction in the Department of Cranio-Maxillofacial and Oncological Surgery, Medical University of Lodz, Poland. The patients were examined and asked about the antibiotic and/or NSAIDs therapy. Only patients with the drug implementation of at least $48 \mathrm{~h}$ of NSAIDs and 5 days of antibiotic therapy at the moment of surgery were included in the study. The evaluated drugs were clindamycin (300 mg every $8 \mathrm{~h}$ ) [25] and ibuprofen (200 mg twice a day). Patients did not report on any other drug intake for any reason. The specimens were divided into four groups according to the type of drug that the patient was taking: group 0 (control)—no drug $(n=25)$; group I-NSAID $(n=7)$; group II—systemic antibiotics $(n=5)$; and group III-NSAID and antibiotics $(n=5)$. The specimens were immediately fixed with $300 \mu \mathrm{L}$ of lysate buffer, frozen at $-70^{\circ} \mathrm{C}$, immersed in liquid nitrogen, filled with sample buffer and centrifuged to obtain the supernatant. All the procedures were conducted in accordance with the principles of the Declaration of Helsinki and were approved by the Ethical Committee on Human Research of the Medical University of Lodz (RNN/34/08/KE). Oral and written informed consent was obtained from all participants in the study.

\subsection{VEGF Quantification Using Enzyme-Linked Immunosorbent Assay}

In all the groups, VEGF levels were measured using a RayBio Human VEGF ELISA kit (RayBiotech Inc.) according to the manufacturer's specifications. A standard curve was calculated over a concentration range of $10-100 \mu \mathrm{g} / 0.5 \mathrm{~mL}$. The values of VEGF levels were provided by the regression equation and read using an Elx800 platelet reader at a wavelength of 450 (Bio-Tek Instruments Inc.). All the results were calculated for one gram of tissue under study and analyzed using ANOVA $(\mathrm{P}<0.05)$ and the Fisher post-hoc test. All tests were performed using PQSTAT SOFTWARE 1.6.2.

\subsection{Determination of VEGFA and VEGFB Gene Expression}

All 42 samples of periapical inflamed tissues underwent qualitative gene expression analysis. In the first step of the analysis, the PCR product from the reference gene $A C T B$ was detected in all specimens. Therefore, all samples were included in the qualitative analysis of VEGFA and VEGFB gene expression.

To detect gene expression, $1 \mathrm{~mL}$ of Fenozol (chaotropic salts and phenol; A\&A Biotechnology, Poland) was added to the granulomatous tissue to isolate RNA using a Total RNA Mini Plus kit (A\&A Biotechnology, Poland). The isolated RNA had an A260/280 ratio of 1.8-1.9. RNA samples were stored at $-76^{\circ} \mathrm{C}$ before analysis. Reverse transcriptase (RT) reaction was performed using an Enhanced Avian HS RT-PCR kit (Sigma Aldrich, Munich, Germany) according to the manufacturer's two-step protocol. For the first step it contained $0.1 \mu \mathrm{g} / \mu \mathrm{L}$ of total RNA, $1 \mu \mathrm{L}$ of anchored oligo(dT) primer (final concentration: $3.5 \mu \mathrm{M}$ ), $1 \mu \mathrm{L}$ of dNTPs mix (final concentration: $500 \mu \mathrm{M}$ each dNTP) and deionized, nuclease-free water. The mixture was centrifuged and incubated at $70{ }^{\circ} \mathrm{C}$ for $10 \mathrm{~min}$. After that, it was chilled on ice, and the following components for the second step were added: $2 \mu \mathrm{L}$ of 10X buffer for AMV-RT, $1 \mu \mathrm{L}$ of RNase inhibitor $(1 \mathrm{U} / \mu \mathrm{L})$ and $1 \mu \mathrm{L}$ of Enhanced Avian RT $(1 \mathrm{U} / \mu \mathrm{L})$. It was then mixed, centrifuged and incubated at $42{ }^{\circ} \mathrm{C}$ for $50 \mathrm{~min}$. Total volume was $20 \mu \mathrm{L}$. cDNA was used immediately or stored at $-20^{\circ} \mathrm{C}$. Number of cycles was 35 , and annealing temperature was $57^{\circ} \mathrm{C}$ for VEGF-A and $56^{\circ} \mathrm{C}$ for VEGF-B.

Gene expression was detected using qualitative polymerase chain reaction (PCR). The mixture for PCR amplification consisted of a cDNA template, $0.7 \mu \mathrm{L}$ of each primer (target genes: VEGFA F 5'-GACCAAAGAAGATAGAGCAAG-3', R 5'-ATACGCTCCAGGACTTATTAC-3'; VEGFB F 5'-GAAAGTGGTGTCATGGATAG-3' ${ }^{\prime}$, R 5' -ATGAGCTCCACAGTCAAG-3'; reference gene: АСТВ F 5'-GTGGGGCGCCCCAGGCACCA-3'; R 5'-CTCCTTAATGTCAC GCACGATTTC-3'), $10 \mu \mathrm{L}$ of JumpStart RedTaq ReadyMix PCR Reaction Mix (Sigma Aldrich, Munich, Germany) and water to a final volume of $20 \mu \mathrm{L}$. Negative and positive 
controls were included in each PCR run. The negative control was a sample without a cDNA template. The positive control contained cDNA obtained from human umbilical vein endothelial cells (HUVEC) that express VEGFA and VEGFB. PCR products were analyzed by electrophoresis on $2 \%$ agarose gel. PCR product size for qualitative analysis was 466 bp for $A C T B, 105 \mathrm{bp}$ for VEGFA and $84 \mathrm{bp}$ for VEGFB. Some examples of electrophoretic separation of PCR products are shown for the VEGFA and VEGFB genes in Figures 1 and 2.

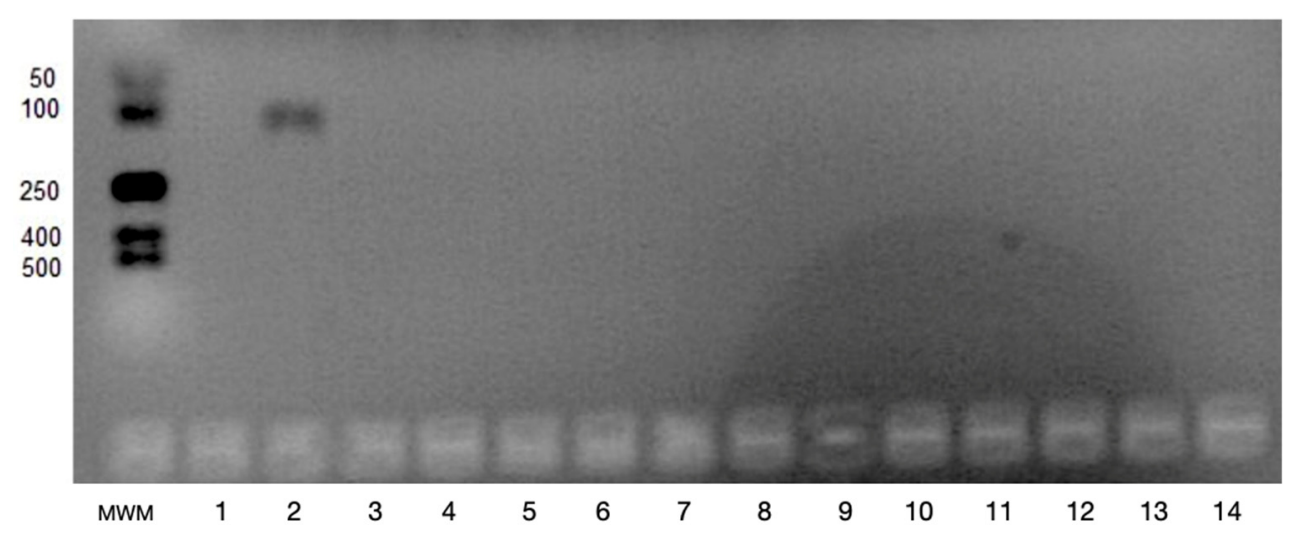

Figure 1. Example of electrophoretic separation of PCR products for VEGFA, MWM-molecular weight marker (50-500 bp); 1-negative control; 2-positive control; 3-14-samples (105 bp).

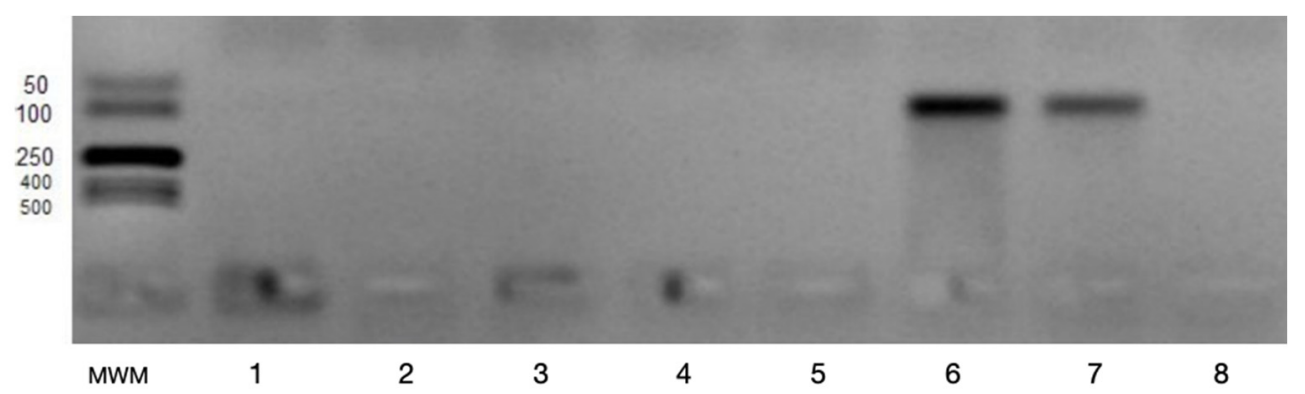

Figure 2. Example of electrophoretic separation of PCR products for VEGF-B, MWM-molecular weight marker (50-500 bp); 1-6-samples (84 bp); 7-positive control; 8-negative control.

\section{Results}

ELISA analysis revealed that mean VEGF levels in inflamed periapical tissue of patients in the three treatment groups were significantly lower than those of control patients, who did not take any drugs $(10.4324 \mathrm{ng} / \mathrm{mL}$, ANOVA $p=0.008)$. Mean VEGF levels were $6.0967 \mathrm{ng} / \mathrm{mL}$ for group I (NSAIDs), $5.6609 \mathrm{ng} / \mathrm{mL}$ for group II (Antibiotics) and $7.1419 \mathrm{ng} / \mathrm{mL}$ for group III (NSAID and antibiotics) (Figure 3). Post-hoc analysis revealed that only the VEGF level in group III (NSAIDs and antibiotics) was not significantly different from the mean VEGF level in the control group $(p=0.07)$. Analysis of the VEGF level for the I and II group in comparison to the control group was statistically significant (Table 1).

The qualitative expression of genes was analyzed in all samples. VEGFA expression was not found in any of the samples, whereas VEGFB expression was detected in $61.9 \%$ of the samples. Additionally, the percentage distribution of VEGFB expression was determined in each group. It was found in $42.8 \%, 80.0 \%$, and $100 \%$ samples of group I, II, and III, respectively. In the control group, in which no drug was used, VEGFB expression was detected in 14 out of 25 samples (56.0\%). 


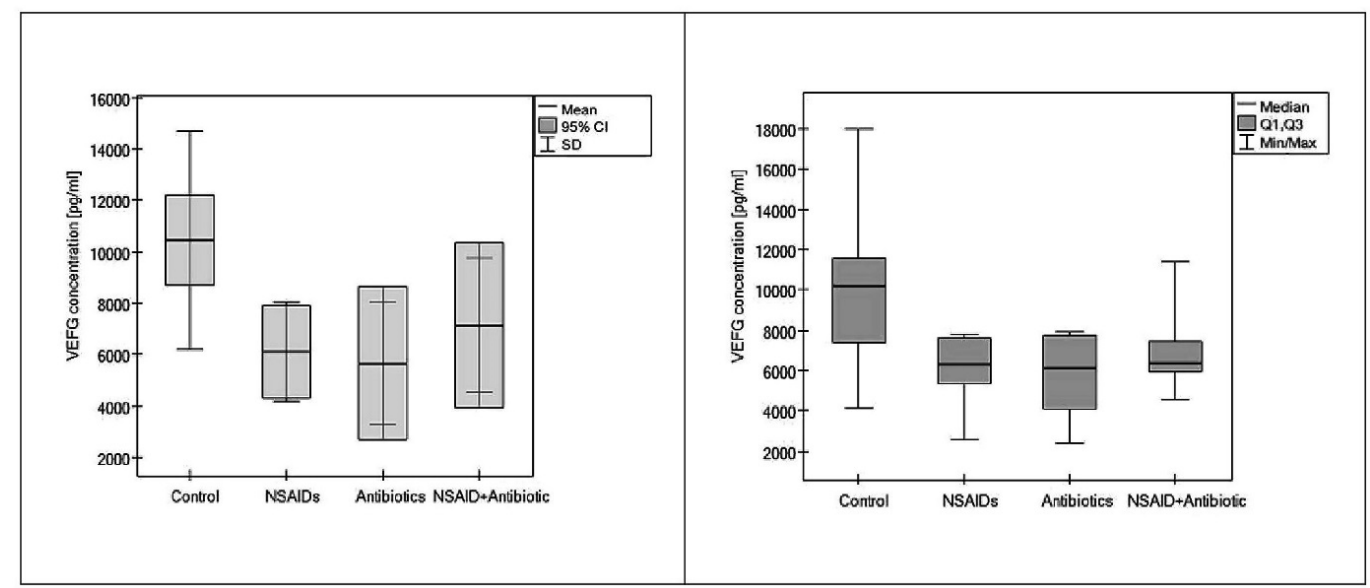

Figure 3. VEGF concentration in all groups of patients: group I (NSAIDs), group II (antibiotics), group II (NSAID and antibiotics) and control group (no drug treatment).

Table 1. Differences of VEGF concentration among tested groups and the control group.

\begin{tabular}{ccc}
\hline Group & $\boldsymbol{n}$ & $\begin{array}{c}\text { VEGF Concentration }(\mathbf{n g} / \mathrm{mL}) \\
\text { Mean } \pm \text { SD }\end{array}$ \\
\hline 0 & 25 & $10.4324 \pm 4257.2$ \\
I & 7 & $6.0967 \pm 1929.6^{*}$ \\
II & 5 & $5.6609 \pm 2394.9^{+}$ \\
III & 5 & $7.1419 \pm 2600.8^{\#}$ \\
\hline
\end{tabular}

*0 vs. I $p=0.008,{ }^{\dagger} 0$ vs. II $p=<0.01,{ }^{\#} 0$ vs. III $p=<0.07$.

\section{Discussion}

VEGF plays an important role in vascular remodeling and immune processes in periapical diseases [26]. Furthermore, it participates in both the initiation and progression of periodontal inflammation and in the healing of periodontal diseases [7]. Many inflammatory cytokines have a significant effect on angiogenesis, as they upregulate or downregulate VEGF expression. Overexpression of VEGF in many diseases induces more severe inflammation. The recruitment of inflammatory cells is important in the pathogenesis of chronic periapical periodontitis, a disease with long-term consequences that result in damaged supporting tissues, including alveolar bone resorption around the apical region and formation of inflamed periapical tissue with an elevated number of inflammatory cells [27]. In patients with periodontitis, VEGF levels are higher in diseased periodontal tissue than in clinically healthy tissue. VEGF mRNA expression is significantly greater in periapical granulomas than in healthy gingival tissues [28]. VEGF has a fundamental role in the progression of periodontal disease, and VEGF levels are correlated with severity of periodontitis [29].

Bone remodeling is also a dynamic balance between two processes: bone removal by osteoclasts and new bone formation by osteoblasts. VEGF regulates bone remodeling by stimulating osteoblast differentiation [30]. According to Yang et al., VEGF may be involved in osteoclastic differentiation and in intensification of osteoclastic bone-resorbing activity [31]. Previous studies indicate [32-34] that blocking VEGF activity in chronic inflamed tissue may inhibit disease progression. In the present study, pharmacotherapy decreased VEGF concentrations in periapical inflamed tissues. Moreover, lowering VEGF levels with systemic NSAIDs and antibiotics may diminish the development of inflammatory granulomatous tissue formation.

Unfortunately, VEGF levels that are either too high or too low may have negative consequences. Galiano et al. [35] found that diminished production of VEGF leads to decreased angiogenesis, a common reason for impaired tissue repair. VEGF acts as an endothelial cell mitogen, chemotactic agent and inducer of vascular permeability. VEGF is essential for 
normal tissue repair because of its effects on multiple components of the wound healing cascade, including collagen deposition, angiogenesis and epithelization. VEGF seems to activate mononuclear cells and promote the closure of nonhealing skin ulcers $[36,37]$. Galiano et al. [35] suggest that topical VEGF may improve healing by mobilizing bone marrow-derived cells and up-regulating factors. Unfortunately, many questions about the complex nature of angiogenesis, granulation tissue formation, bone resorption and bone healing induced by VEGF in chronic periapical periodontitis remain unanswered.

Systemic or local antibiotics may be applied according to the severity of the patient's signs and symptoms [38]. For the short-term treatment of an acute or locally persistent periodontal infection, systemic antibiotics that thwart pathogenic microorganisms are indicated [39]. Although the presence of periodontal pathogens is essential for the onset of periodontitis, these organisms do not sustain disease progression. In fact, the host immune response modulates the disease toward destruction or healing [40]. The microbial colonization and intensive immunological reaction during disease exacerbation lead to the destruction of the periapical tissue and the formation of several periapical lesions. An ongoing disease process at the interface between infected root pulp and periodontal ligament results in local inflammation and has long-term effects, such as various histopathological types of apical periodontitis, commonly referred to as periapical lesions [41]. Systemic antibiotic therapy ensures the appropriate concentration of drugs in inflamed tissues, reaching microorganisms that are not disturbed by instruments or topical antibiotic therapy [40]. Despite the need for non-surgical root canal procedures, the selection of systemic adjuvant drug treatments with combined antiangiogenic activity may also be important in preventing infection.

A review of previous studies revealed that VEGF-A has strong angiogenic properties. Interestingly, despite early discovery and high sequence homology to the other VEGF family members, VEGF-B seems to have different biological functions [14]. Its antiapoptotic and survival effect on multiple types of vascular cells, and not a necessarily angiogenic activity, may be essential in chronic periapical lesions. In this study, expression of both $V E G F A$ and VEGFB genes was analyzed in periapical granulation tissue. VEGFA expression was not found in any of the samples, whereas $V E G F B$ gene expression was detected in more than $60 \%$ of the samples. Furthermore, VEGFB expression was more frequently evident in the group of specimens collected from patients taking antibiotics $(80 \%$ and $100 \%$ of samples in groups II and III; Table 2). This suggests that antibiotics, which induce anti-inflammatory mechanisms, may also promote $V E G F B$ gene expression and promote antiapoptotic activity. Enholm et al. [42] showed that the three VEGF genes were regulated in a strikingly different manner, suggesting that they serve distinct, although perhaps overlapping, functions in vivo. Similarly, Garlet et al. [43] analyzed 84 genes represented in the wound healing PCR array panel and found that there was no marked increase of VEGFA gene expression in periapical granulomas when compared with healthy periodontal ligament tissue. VEGFB gene expression was not assessed. Further studies should be conducted to describe the desirable effects of systemic drug treatment on the levels of specific types of VEGF-A and VEGF-B in wound healing and resorptive processes in oral diseases. To date there are no data explaining these mechanisms. Nie et al. [44] analyzed VEGF protein expression after the treatment with deferoxamine and rapamycin in rats that underwent ischemia and hypoxia using real-time quantitative fluorescent PCR and Western blot techniques. They found that deferoxamine promoted wound healing, whereas the effect of rapamycin was the opposite [44]. Unfortunately, most of their study data did not include drugs commonly used in dentistry and did not refer to dental tissues.

Novel markers of immune activation and inflammation (suPARs) raise hopes of accurately assessing the impact of activation of local inflammatory foci. In immunologically compromised patients $[45,46]$, e.g., prior to bone marrow transplantation, aggressive systemic treatment in leukemia, or radiochemotherapy of the head and neck region, the detection of activating dentate inflammatory foci in lymphoma would be invaluable. 
The small sample size along with the possibility of cultural microbial differences in periodontal biofilm may be highly definitive for the outcomes and they require further inquiry.

Table 2. The results for the VEGFA and VEGFB gene expression in the studied groups of samples.

\begin{tabular}{cccc}
\hline \multicolumn{2}{c}{ Gene VEGFA N (\%) } & \multicolumn{2}{c}{ Gene VEGFB N (\%) } \\
\hline Presence of gene expression & $0(0.0 \%)$ & Presence of gene expression & $26(61.9 \%)$ \\
\hline Absence of gene expression & $42(100.0 \%)$ & Absence of gene expression & $16(38.1 \%)$ \\
\hline
\end{tabular}

\section{Conclusions}

The absence of VEGFA expression and the identification of VEGFB expression in periapical inflamed tissues should be the subject of thorough investigations in the future. Studies should focus on specific isoforms of VEGF gene expression in inflamed human periapical tissues. The findings in this study may suggest that adjuvant treatments, in the form of NSAIDs and antibiotics, may alleviate VEGF-connected consequences of the progression of apical periodontitis. However, the mechanisms of formation of apical lesions and the exact role of VEGF in that process remain unclear.

Author Contributions: Conceptualization, A.P.-U. (designed the study, collected the samples, wrote the manu-script) and M.M.; methodology, A.P.-U., M.M., E.B; software A.P.-U., A.D.; validation, A.P.-U., M.M., J.A.P.d.F.; formal analysis, A.P.-U.; investigation, A.P.-U.; M.M., A.D.; A.S.-K.; E.B. (molecular PCR evaluation); and B.M. (the tissue biopsies collected during surgeries done by B.M.); resources, A.P.-U.; M.M., data curation, A.P.-U.; writing—original draft preparation, A.P.-U.; writingreview and editing, A.P.-U., M.M., J.A.P.d.F., E.B., A.S.-K.; visualization, A.P.-U., M.M.; supervision, A.P.-U., M.M., E.B.; project administration, A.P.-U.; funding acquisition, A.P.-U. All authors have read and agreed to the published version of the manuscript.

Funding: This work was supported by grant no. 502-12-766 and 503/2-044-02/503-21-001-17 from the Medical University of Lodz.

Institutional Review Board Statement: The study was conducted according to the guidelines of the Declaration of Helsinki, and approved by the Clinical Research Ethics Board of Medical University of Lodz (certificate number RNN/34/08/KE).

Informed Consent Statement: Informed consent was obtained from all subjects involved in the study.

Data Availability Statement: Not applicable.

Conflicts of Interest: The authors declare no conflict of interest.

\section{References}

1. Keles, G.C.; Cetinkaya, B.O.; Eroglu, C.; Simsek, S.B.; Kahraman, H. Vascular endothelial growth factor expression levels of gingiva in gingivitis and periodontitis patients with/without diabetes mellitus. Inflamm. Res. 2010, 59, 543-549. [CrossRef] [PubMed]

2. Fonseca-Silva, T.; Santos, C.C.O.; Alves, L.R.; Dias, L.C.; Brito-Junior, M.; De Paula, A.M.B.; Guimaraes, A.L.S. Detection and quantification of mast cell, vascular endothelial growth factor, and microvessel density in human inflammatory periapical cysts and granulomas. Int. Endod. J. 2012, 45, 859-864. [CrossRef]

3. Rubini, C.; Arrese, L.; Zizzi, A.; Fioroni, M.; Ascani, G.; Poteri, G.; Stramazzotti, D.; Piccirilli, M.; Iezzi, G.; Piatelli, A. Immunohistochemical expression of vascular endothelial growth factor (VEGF) in different types of odontogenic cysts. Clin. Oral Investig. 2011, 15, 757-761. [CrossRef] [PubMed]

4. Bletsa, A.; Virtej, A.; Berggreen, E. Vascular endothelial growth factors and receptors are up-regulated during development of apical periodontitis. J. Endod. 2012, 38, 628-635. [CrossRef] [PubMed]

5. Veeriah, V.; Paone, R.; Chatterjee, S.; Teti, A.; Capulli, M. Osteoblasts Regulate Angiogenesis in Response to Mechanical Unloading. Calcif. Tissue Int. Epub. 2018. Ahead of Print. [CrossRef] [PubMed]

6. Ergolu, Z.T.; Kurtis, B.; Altug, H.A.; Sahin, S.; Tuter, G.; Baris, E. Effect of topical ozonetherapy on gingival wound healing in pigs: Histological and immuno-histochemical analysis. J. Appl. Oral Sci. 2018, 10, 27. [CrossRef]

7. Cetinkaya, B.O.; Keles, G.C.; Ayas, B.; Sakallioglu, E.E.; Acikgoz, G. The expression of vascular endothelial growth factor in a rat model at destruction and healing stages of periodontal disease. J. Periodontol. 2007, 78, 1129-1135. [CrossRef] [PubMed] 
8. Folkman, J. Angiogenesis: An organizing principle for drug discovery? Nat. Rev. Drug Discov. 2007, 6, 273-286. [CrossRef] [PubMed]

9. Ferrara, N.; Kerbel, R.S. Angiogenesis as a therapeutic target. Nature 2005, 438, 967-974. [CrossRef] [PubMed]

10. Alitalo, K.; Tammela, T.; Petrova, T.V. Lymphangiogenesis in development and human disease. Nature 2005, 438, $946-953$. [CrossRef]

11. Lohela, M.; Bry, M.; Tammela, T.; Alitalo, K. VEGFs and receptors involved in angiogenesis versus lymphangiogenesis. Curr. Opin. Cell Biol. 2009, 21, 154-165. [CrossRef]

12. Grimmond, S.; Lagercrantz, J.; Drinkwater, C.; Silins, G.; Townson, S.; Pollock, P.; Gotley, D.; Carson, E.; Rakar, S.; Nordenskj, O.M.; et al. Cloning and characterization of a novel human gene related to vascular endothelial growth factor. Genome Res. 1996, 6, 124-131. [CrossRef]

13. Eriksson, L.X.; Novel, U. VEGF family members: VEGF-B, VEGF-C and VEGF-D. Int. J. Biochem. Cell Biol. 2001, 33, 421-426.

14. Li, X.; Lee, C.; Tang, Z.; Zhang, F.; Arjunan, P.; Li, Y.; Hou, X.; Kumar, A.; Dong, L. VEGF-B: A survival, or an angiogenic factor? Cell Adh. Migr. 2009, 3, 322-327. [CrossRef]

15. Zwolinska-Wcislo, M.; Krzysiek-Maczka, G.; Ptak-Belowska, A.; Karczewska, E.; Pajdo, R.; Sliwowski, Z.; Urbanczyk, K.; Drozdowicz, D.; Konturek, S.J.; Pawlik, W.W.; et al. Antibiotic treatment with ampicillin accelerates the healing of colonic damage impaired by aspirin and coxib in the experimental colitis. Importance of intestinal bacteria, colonic microcirculation and proinflammatory cytokines. J. Physiol. Pharmacol. 2011, 62, 357-368. [PubMed]

16. Kwiatkowska, B.; Maślińska, M. Macrolide therapy in chronic inflammatory diseases. Mediat. Inflamm. 2012, $2012,636157$. [CrossRef] [PubMed]

17. Mathe, Z.; Dupraz, P.; Rinsch, C.; Thorens, B.; Bosco, D.; Zbinden, M.; Morel, P.; Berney, T.; Pepper, M.S. Tetracycline-regulated expression of VEGF-A in beta cells induces angiogenesis: Improvement of engraftment following transplantation. Cell Transplant. 2006, 15, 621-636. [CrossRef] [PubMed]

18. Palatynska-Ulatowska, A.; Michalska, M.; Łazarenkow, A. Fibrinogen, bFGF and VEGF levels during antibiotic therapy in gynecologic cancer: A preliminary report. Indian J. Biochem. Biophys. 2014, 51, 230-236. [PubMed]

19. Pakneshan, P.; Birsner, A.E.; Adini, I.; Becker, C.M.; D’Amato, R.J. Differential suppression of vascular permeability and corneal angiogenesis by nonsteroidal anti-inflammatory drugs. Investig. Ophthalmol. Vis. Sci. 2008, 49, 3909-3913. [CrossRef] [PubMed]

20. Nadar, S.; Blann, A.D.; Lip, G.Y.H. Effects of aspirin on intra-platelet vascular endothelial growth factor angiopoietin-1, and P-selectin levels in hypertensive patients. Am. J. Hypertens. 2006, 19, 970-977. [CrossRef] [PubMed]

21. Zhang, N.; Tao, K.; Huang, T. Effects of meloxicam on vascular endothelial growth factor and angiopoietin-2 expression in colon carcinoma cell line HT-29. J. Huazhong Univ. Sci. Med. 2000, 27, 399-402. [CrossRef]

22. Jayadev, M.; Karunakar, P.; Vishwanath, B.; Soumya Chinmayi, S.; Siddhartha, P.; Chaitanya, B. Knowledge and pattern of antibiotic and non-narcotic analgesic prescription for pulpal and periapical pathologies-A survey among dentists. J. Clin. Diag. Res. 2014, 8, 10-14. [CrossRef] [PubMed]

23. Salako, N.O.; Rotimi, V.O.; Adib, S.M.; Al-Mutawa, S. Pattern of antibiotic prescription in the management of oral diseases among dentists in Kuwait. J. Dent. 2004, 32, 503-509. [CrossRef]

24. Garcia, V.G.; Takano, R.Y.; Fernandes, L.A.; De Almeida, J.M.; Theodoro, L.H. Treatment of experimental periodontal disease by a selective inhibitor of cyclooxygenase-2 with scaling and root planing (SRP). Inflammopharmacology 2010, 18, $293-301$.

25. Addy, L.D.; Martin, M.V. Clindamycin and dentistry. Br. Dent. J. 2005, 199, 23-26. [PubMed]

26. Virtej, A.; Løes, S.S.; Berggreen, E.; Bletsa, A. Localization and signaling patterns of vascular endothelial growth factors and receptors in human periapical lesions. J. Endod. 2013, 39, 605-611.

27. Takeichi, O.; Hama, S.; Iwata, K.; Ito, K. Confocal immunolocalization of VE-Cadherin- and CXC chemokine-expressing endothelial cells in periapical granulomas. Int. Endod. J. 2008, 41, 401-407.

28. Kudo, H.; Takeichi, O.; Hatori, K.; Makino, K.; Himi, K.; Ogiso, B.A. potential role for the silent information regulator 2 homologue 1 (SIRT1) in periapical periodontitis. Int. Endod. J. 2018, 51, 747-757.

29. Prapulla, D.V.; Pai, B.S.; Pradeep, R. Gingival crevicular fluid VEGF levels in periodontal health and disease. J. Periodontol. 2007, 78, 1783-1787. [CrossRef] [PubMed]

30. Samee, M.; Kasugai, S.; Kondo, H.; Ohya, K.; Shimokawa, H.; Kuroda, S. Bone morphogenetic protein-2 (BMP2) and vascular endothelial growth factor (VEGF) transfection to human periosteal cells enhances osteoblast differentiation and bone formation. $J$. Pharmacol. Sci. 2008, 108, 18-31.

31. Yang, Y.Q.; Tan, Y.Y.; Wong, R.; Wenden, A.; Zhang, L.K.; Rabie, B.M. The role of vascular endothelial growth factor in ossification. Int. J. Oral Sci. 2012, 4, 64-68. [CrossRef] [PubMed]

32. Angelo, L.S.; Kurzrock, R. Vascular endothelial growth factor and its relationship to inflammatory mediators. Clin. Cancer Res. 2007, 13, 2825-2830.

33. Heasman, P.; Hughes, J. Drugs, medications and periodontal disease. Br. Dent. J. 2014, 217, 411-419.

34. Seymour, R.A. Effects of medications on the periodontal tissues in health and disease. Periodontology 2006, 40, 120-129. [CrossRef]

35. Galiano, R.D.; Tepper, O.M.; Pelo, C.R.; Bhatt, K.A.; Callaghan, M.; Bastidas, N.; Bunting, S.; Steinmetz, H.G.; Gurtner, G.C. Topical vascular endothelial growth factor accelerates diabetic wound healing through increased angiogenesis and by mobilizing and recruiting bone marrow-derived cells. Am. J. Pathol. 2004, 164, 1935-1947. 
36. Takahashi, H.; Masabumi, S. The vascular endothelial growth factor (VEGF)/VEGF receptor system and its role under physiological and pathological conditions. Clin. Sci. 2005, 109, 227-241.

37. Bao, P.; Kodra, A.; Tomic-Canic, M.; Golinko, M.S.; Ehrlich, H.P.; Brem, H. The role of vascular endothelial growth factor in wound healing. J. Surg. Res. 2009, 153, 347-358. [PubMed]

38. Leszczyńska, A.; Buczko, P.; Buczko, W.; Pietruska, M. Periodontal pharmacotherapy-An updated review. Adv. Med. Sci. 2011, 56, 123-131. [CrossRef] [PubMed]

39. Harini, G.; Kaarthikeyan, G. Advanced drug delivery systems in treating periodontal diseases-A review. J. Dent. Med. Sci. 2014, 13, 2279-2861.

40. Pejcic, A.; Kesic, L.; Brkic, Z.; Pesic, Z.; Mirkovic, D. Effect of periodontal treatment on lipoproteins levels in plasma in patients with periodontitis. South Med. J. 2011, 104, 547-552. [PubMed]

41. Nair, P.N.R. Pathogenesis of apical periodontitis and the causes of endodontic failures. Crit. Rev. Oral. Biol. Med. 2004, 15, 348-381. [CrossRef]

42. Enholm, B.; Paavonen, K.; Ristimäki, A.; Kumar, V.; Gunji, Y.; Klefstrom, J.; Kivinen, L.; Laiho, M.; Olofsson, B.; Joukov, V.; et al. Comparison of VEGF, VEGF-B, VEGF-C and Ang-1 mRNA regulation by serum, growth factors, oncoproteins and hypoxia. Oncogene 1997, 14, 2475-2483. [CrossRef]

43. Garlet, G.P.; Horwat, R.R., Jr.; Ray, H.L.J.; Garlet, T.P.; Silveira, E.M.; Campanelli, A.P.; Trombone, A.P.; Letra, A.; Silva, R.M. Expression Analysis of Wound Healing Genes in Human Periapical Granulomas of Progressive and Stable Nature. J. Endod. 2012, 38, 185-190. [CrossRef] [PubMed]

44. Nie, K.; Hu, P.; Wang, D.; Wei, Z.; Zeng, X.; Sun, G. Effects of rapamycin and deferoxamin on wound healing after ischemia and hypoxia. Zhongguo Xiu Fu Chong Jian Wai Ke Za Zhi 2017, 31, 718-722. [PubMed]

45. Kozakiewicz, M.; Wlazeł, R.N. Does Soluble Urokinase-Type Plasminogen Activator Receptor Level Predicts the Occurrence of Inflammatory Complications in Maxillofacial Surgery? Appl. Sci. 2021, 11, 2192. [CrossRef]

46. Kozakiewicz, M.; Trzcińska-Kubik, M.; Wlazel, R. Index of Body Inflammation for Maxillofacial Surgery Purpose-to Make the Soluble Urokinase-Type Plasminogen Activator Receptor Serum Level Independent on Patient Age. Appl. Sci. 2021, $11,1345$. [CrossRef] 